\title{
Discussing Uncertainty and Risk in Primary Care: Recommendations of a Multi-Disciplinary Panel Regarding Communication Around Prostate Cancer Screening
}

\author{
Michael Wilkes, $M D, P h D^{7}$, Malathi Srinivasan, $M D^{7}$, Galen Cole, $P h D, M P H, L P C^{2}$, \\ Richard Tardif, PhD ${ }^{3}$, Lisa C. Richardson, MD, MPH' ${ }^{2}$, and Marcus Plescia, MD, MPH \\ 1. University of California, Davis School of Medicine, Sacramento, CA, USA; ${ }^{2}$ National Center for Chronic Disease Prevention and Health \\ Promotion, Centers for Disease Control and Prevention, Atlanta, GA, USA; ${ }^{3}$, Oak Ridge Institute for Science and Education, Oak Ridge, TN, \\ USA.
}

BACKGROUND: Shared decision making improves value-concordant decision-making around prostate cancer screening (PrCS). Yet, PrCS discussions remain complex, challenging and often emotional for physicians and average-risk men.

OBJECTIVE: In July 2011, the Centers for Disease Control and Prevention convened a multidisciplinary expert panel to identify priorities for funding agencies and development groups to promote evidence-based, value-concordant decisions between men at average risk for prostate cancer and their physicians.

DESIGN: Two-day multidisciplinary expert panel in Atlanta, Georgia, with structured discussions and formal consensus processes.

PARTICIPANTS: Sixteen panelists represented diverse specialties (primary care, medical oncology, urology), disciplines (sociology, communication, medical education, clinical epidemiology) and market sectors (patient advocacy groups, Federal funding agencies, guidelinedevelopment organizations).

MAIN MEASURES: Panelists used guiding interactional and evaluation models to identify and rate strategies that might improve PrCS discussions and decisions for physicians, patients and health systems/society. Efficacy was defined as the likelihood of each strategy to impact outcomes. Effort was defined as the relative amount of effort to develop, implement and sustain the strategy. Each strategy was rated $(1-7$ scale; $7=$ maximum) using group process software (ThinkTank $^{\mathrm{TM}}$ ). For each group, intervention strategies were grouped as financial/regulatory, educational, communication or attitudinal levers. For each strategy, barriers were identified.

KEY RESULTS: Highly ranked strategies to improve value-concordant shared decision-making (SDM) included: changing outpatient clinic visit reimbursement to reward SDM; development of evidence-based, technology-assisted, point-of-service tools for physicians

Electronic supplementary material The online version of this article (doi:10.1007/s11606-013-2419-z) contains supplementary material, which is available to authorized users.

Received March 8, 2012

Revised August 22, 2012

Accepted December 5, 2012

Published online May 7, 2013 and patients; reframing confusing prostate cancer screening messages; providing pre-visit decision support interventions; utilizing electronic health records to promote benchmarking/best practices; providing additional training for physicians around value-concordant decisionmaking; and using re-accreditation to promote training.

CONCLUSIONS: Conference outcomes present an expert consensus of strategies likely to improve valueconcordant prostate cancer screening decisions. In addition, the methodology used to obtain agreement provides a model of successful collaboration around this and future controversial cancer screening issues, which may be of interest to funding agencies, educators and policy makers.

KEY WORDS: prostate cancer screening; men's health; shared decisionmaking; communication; funding priorities; risk.

$\mathrm{J}$ Gen Intern Med 28(11):1410-9

DOI: $10.1007 / \mathrm{s} 11606-013-2419-\mathrm{z}$

(C) The Author(s) 2013. This article is published with open access at Springerlink.com

\section{BACKGROUND}

How can screening for life-threatening diseases be harmful?

While many screening tests have improved the quantity and quality of a person's life through early detection of lifethreatening or life-altering diseases, other tests have failed to deliver. These tests may fail to deliver because they are inaccurate, poorly performing, have unavailable treatments, high costs, treatment complications or health providers who are unaware of the screening controversies. Prostate cancer screening with the prostate-specific antigen (PSA) blood test epitomizes this controversy. Prostate cancer accounts for about 29,000 cancer deaths annually in the US, yet millions of men may have undetected prostate cancer - the vast majority of whom will remain asymptomatic throughout their life. ${ }^{1-4}$ At the population level, prostate cancer treatment has only a marginal mortality benefit. PSA as a screening test has reasonable sensitivity to detect aggressive prostate cancers $(91 \%)$, but cannot distinguish between low- 
and high-risk prostate cancers. This results in substantial overdiagnosis (with attendant treatment complications of impotence, incontinence and surgical mortality) of men who would have remained asymptomatic. ${ }^{1-4}$

For controversial conditions such as prostate cancer screening (PrCS), the medical encounter needs to focus on discussion and education to help patients reach valueconcordant decisions. ${ }^{5-11}$ Value-concordant decision-making can be enhanced using shared decision-making ${ }^{8}$ techniques to clarify issues. In SDM, medical knowledge (risks, harms and benefits of diagnosis and treatment) is cogently and clearly contextualized through the lens of patient's values and preferences to elicit a preferred clinical pathway.

Most major professional societies have endorsed SDM for decisions around prostate cancer screening for average-risk men aged 55-75 years old. ${ }^{2,3,12-15}$ In 2010, the American Cancer Society updated its PrCS recommendations to include an informed decision-making/SDM discussion about screening with the PSA test for all men who had a longer than 10year life expectancy. ${ }^{15}$ Until recently, the US Preventive Services Task Force (USPSTF) considered the evidence insufficient to recommend for or against prostate cancer screening in this age range, but they encouraged shared decision-making. ${ }^{3}$ In 2011, the USPSTF recommended against routine $\mathrm{PrCS}$ for average-risk men of all ages. ${ }^{3,16}$

Yet, balanced discussions between clinicians and patients about disease screening remain problematic. ${ }^{17}$ Objective disease screening discussions are colored by over 50 years of public health efforts that convey "do not delay" messages for cancer screening. ${ }^{18}$ Overall, the public has an enthusiasm for health screening. This enthusiasm for cancer screening persists even when they understand the risks of false-positive results-identifying "abnormalities" that have a dubious impact on health but may result in a cascade of costly and often aggressive medical interventions. ${ }^{19}$ At the same time, physicians often worry about liability issues that might arise from missed diagnosis resulting from a decision not to screen..$^{20,21}$ Primary care physicians have limited time for complex medical discussions, have limited training in effective SDM techniques ${ }^{6,8,22}$ and are often not up to date on the latest evidence. Additionally, tension exists between specialists who see patients with advanced disease (and therefore push for aggressive screening) and primary care/ population health groups who see the myriad of complications from over-diagnosis.

As such, public and private agencies are seeking methods to help patients make complex medical decisions that go beyond providing written material or engaging in brief discussions. Typically, health messages fail for a variety of reasons: the type of message delivered ${ }^{5,23-26}$; method of delivery; lack of message reinforcement; lack of access to recommended care; non-acceptance on the part of the individual; and inappropriate education level. Similarly, expert consensus groups have identified strategies (Fig. 1) to effectively empower patients facing value-sensitive decisions - utilizing SDM, tailoring messages to match cultural background, connecting messages to patient values, assessing readiness to change, targeting messaging to individuals or entities that influence decision-making by the patient (e.g., spouse), utilizing direct patient stories and using decision support interventions. ${ }^{23-27}$ New methods are intended to engage, challenge and motivate patients to make value-concordant health choices, but are not commonly used in clinical practice. ${ }^{10,22,28-32}$

These uncertainties prompted the Centers for Disease Control and Prevention (CDC) to convene a consensus panel to help prioritize communication strategies - to assist patients and physicians in communicating more effectively around prostate cancer screening (PrCS), including PrCS risks, benefits and value preferences. Panel recommendations were intended to help the $\mathrm{CDC}$, public health community and medical communities set priorities for prostate cancer communication methods and in other areas. Here, we describe the process for the panel, main results, implications for PrCS and other health communication.

\section{METHODS The Multidisciplinary Expert Panel}

The CDC convened an expert panel around PrCS communication on June 13-14, 2011, in Atlanta, Georgia. The diverse panel was assembled with experts from across the health care spectrum relevant to PrCS, including individuals with expertise in primary care, oncology, urology, epidemiology, medical education, journalism, health communication and patient advocacy. Participants also included authors of the USPSTF prostate cancer screening evidence report/ guidelines and experts from the CDC's Division of Cancer Prevention and Control (invited panelists listed in Acknowledgements).

\section{Methods}

Prior to the in-person meeting, panelists were assigned to one of three groups (health care provider, patient, health system) based on their background. Groups met by conference call 1-2 times prior to the in-person meeting to share their prostate cancer screening research and experiences and to discuss the literature in their assigned area.

Panelists were asked to accept the PrCS recommendations by the USPSTF 2008 rather than engage in debate around the value of population-based PrCS. Specifically, at the time of the panel, USPSTF 2008 guidelines concluded the evidence was insufficient to assess the balance and harms of PrCS in men younger than 75 years old, with a recommendation for SDM to determine individualized screening decisions. ${ }^{2}$ 
Early in the meeting, three didactic sessions of $60 \mathrm{~min}$ each reviewed the state of the science around prostate cancer screening communication. The first focused on clinician-patient communication, the second focused on patient-directed communication (helping patients make more informed and value-concordant screening decisions) and the third focused on health systems (e.g., system change, electronic health records, reminder systems and social networking). Following each session, panelists discussed methods to improve communication around PrCS focused on the target groups (providers, patients and health systems) with attention to target audiences, specific messaging, health literacy, media and communication channels and program evaluation.

To promote maximum participation and prioritization of ideas by all panelists, we provided each panelist with a laptop computer loaded with "ThinkTank" (GroupSystems, 2011) software. The software allows continuous input of anonymous comments during ongoing discussions and allows all panelists an equal opportunity to express their opinions, preventing individuals from dominating the conversation.

After each session, panelists identified the greatest opportunities to improve decision-making around prostate cancer screening communication. Individuals entered their ideas into ThinkTank ${ }^{\mathrm{TM}}$, and ideas were anonymously projected on a screen for group discussion. Responses were edited and condensed by the facilitator and group, after which each panelist anonymously rated each response on a 7 point scale $(1-7,1=$ minimum, 7 = maximum) for on two domains: (1) effectiveness: likelihood that appropriate implementation of the communication strategy would lead to meaningful improvement in PrCS decision-making and (2) feasibility/effort: the effort required to successfully implement each strategy.

Responses and ratings were displayed for group discussion, and agreement was achieved for major strategies. Panelists listed barriers to each strategy and methods needed to overcome them. We reviewed models of cancer communication, ${ }^{33}$ and based on participant discussion, utilized that discussion to develop an interactional model of elements that might influence patient-physician decisionmaking around PrCS.

Using ThinkTank software, we grouped PrCS strategies into three areas: those intended for providers, patients and health care systems/public health. We then divided the strategies into five content areas: (1) education/knowledge, (2) financial/regulatory, (3) beliefs/attitudes, (4) messaging and (5) communication/ decision-making. For each action, the group discussed benefits and barriers.

\section{RESULTS}

\section{Model Development}

Based on panelist discussion, we developed a model of elements that influenced patient and physician decision-making. The model suggests that patient decisions occur after they have been informed (via physician, health system, decision support interventions, etc.) and have clarified their preferences, values and risk tolerance.

In the model, we only considered influences on the patient-physician interaction, including the knowledge, experience, biases and health literacy of the patient and the physician. Patient decisions were felt to be influenced by their willingness to participate in decisionmaking, trust of the clinician and the source of information, the value they placed on health, the opinion and experiences of family/friends, time and access issues, and competing interests (e.g., financial). Physician advice and decision-making might also be influenced by extreme exemplar cases, limited time to engage in discussions, exposure to opinion leaders/ $\mathrm{CME}$ and institutional policies including quality assurance metrics and competing interests (e.g., patient comorbidities, professional duties). During physician and patient interaction, we assumed that decision-making would involve explanation of content, contextualization of risk-reward, elicitation of values and screening recommendations.

As we further developed the model, we considered contextual elements that influenced the patient-physician interaction, nested in a larger societal and health system context (Fig. 1; expanded Appendix 1). In this model, some patient and physician elements are influenced by context, while others are intrinsic to the individual. Patients interact directly with and are partially influenced by their society and health system. Physicians interacted with and were partially influenced by their health system(s) and societal factors. Finally, society and the health system interact to set the tone, funding and expectations for improved care. The intersection of all of these forces is the point of decision-making.

Participants acknowledged the complexities in making sound, personalized health care decisions around cancer screening-especially prostate cancer. Participants also identified a large number of activities that could improve communication and decision-making.

Physicians. The group identified many barriers to optimal shared decision-making (SDM), but the two judged most important were (1) a shortage of physician time and (2) physician skill at engaging in such 
discussions. The group identified several communication interventions that might improve these shortcomings. Traditional attempts to provide patients with information or empowerment tools utilized brochures and printed messages. Technology-assisted learning now opens opportunities to tailor messages to individual patients, allows interactions between groups of people and collects information from patients that can better inform the health care team.

Based on group ranking regarding strategies to address physician communication issues (Table 1), interventions felt most likely to be effective were (1) changing reimbursement for physicians to promote them spending more time in doctor-patient communication, (2) motivating patients to influence their doctors to engage in SDM, (3) teaching SDM skills in continuing medical education, residency and medical school and (4) requiring SDM discussions as a quality standard in caring for patients between the ages of 50 and 75 . Interventions that the group felt would require the most effort included (1) providing patients with tools that allowed them to prepare for their meeting with the physician, (2) providing doctors with tools to assist in discussions with men and (3) providing specific observed feedback to physicians on their counseling and SDM skills.

Patients. Panelists more easily reached consensus about interventions to improve cancer communication for patients than for providers (Table 2). The group recommended development of a trusted website (information source) that could serve as a one-stop home for high-quality information and decision support interventions on cancer screening. Such a site could use current quality assessment guidelines ${ }^{34}$ to consider which decision support interventions to include/credential. Within the group, there were divisions between the views of specialists and primary care providers about the appropriateness of information related to screening and treatment from a population perspective. Given that the disagreements are unlikely to be resolved, such a website would need to be evidence-based and peer-reviewed; it should avoid being all things to everyone. Participants acknowledged differences between social groups in addressing issues of related to cancer and health screening.

Based on the ranking, the most effective strategies to improve patient PrCS decision-making include: (1) making reliable and accurate educational tools publicly available and (2) empowering patients to have direct conversations with the physicians. Participants also felt men should be engaged outside of the doctor-patient encounter to learn: (1) the importance of making medical decisions in the face of uncertainty; (2) that they can choose various levels of involvement with their doctor, from no involvement to complete involvement; (3) information about the medical condition (prostate cancer) and the decision that needs to be made (to screen or not).

The participants felt the most effective cancer communication intervention directed at patients would be to move some education about PrCS away from the doctor-patient encounter to learning programs, including group meetings led by non-physician health educators. Patient small-group meetings focused on health education have been quite effective in helping patients manage their chronic illnesses. ${ }^{35}$ Such meetings could play an important role in preparing patients to interact with their physicians, answer common questions and thus reduce time needed for doctorpatient discussions.

They also suggested a pre-visit phone call to get patients thinking about these issues as well as framing PrCS discussions as attempts to keep them healthy, not just to look for cancer.

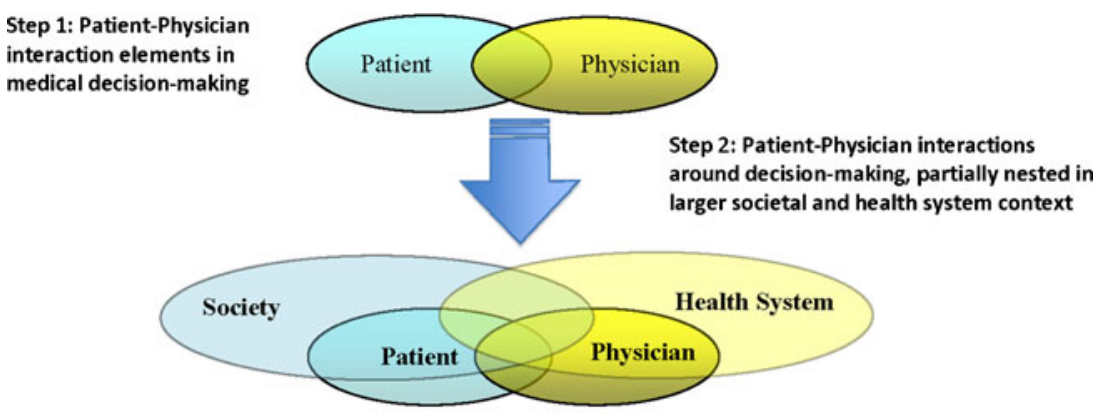

The lives of patients themselves are quite complex, and medical decision-making does not occur in a vacuum. In Step 1, we traditionally consider the patient-physician dyad alone as influencing medical decision-making. Here, we consider that both patient and physician brings their own viewpoints/biases to the medical encounter. However, when viewed in a broader context, as in Step 2, decision-making is influences by a greater variety of sources, notably the society in which the patient participates/lives and the health system in which the physician and patient interact. Each intersection is a point of influence, presenting an opportunity for better engagement and the possibility for disenfranchisement or confusion. Online Appendix 1 enumerates some of the influences for each group and each intersection.

Figure 1. Two-part model of elements influencing medical decisions around complex medical decisions 
Table 1. Improving Physician Behaviors Around Prostate Cancer Screening Discussions

\begin{tabular}{|c|c|c|c|c|}
\hline $\begin{array}{l}\text { Average rank } \\
\text { for effectiveness } \\
\text { in achieving } \\
\text { behavioral } \\
\text { change (1-7, } \\
7=\text { maximum) }\end{array}$ & Theme & Item & Barriers to change related to each item & $\begin{array}{l}\text { Average rank } \\
\text { for effort to } \\
\text { achieve } \\
\text { change (1-7, } \\
7=\text { maximum) }\end{array}$ \\
\hline 6.9 & $\begin{array}{l}\text { Financial and } \\
\text { regulation }\end{array}$ & $\begin{array}{l}\text { Change reimbursement to } \\
\text { incentivize doctor-patient } \\
\text { communication }\end{array}$ & $\begin{array}{l}\text { - If you don't pay you won't get it done } \\
\text { - Will cost system money to increase time for clinicians }\end{array}$ & 3.3 \\
\hline 6.9 & $\begin{array}{l}\text { Communication } \\
\text { and messaging }\end{array}$ & $\begin{array}{l}\text { Have consumers apply pressure } \\
\text { to physicians to engage in SDM }\end{array}$ & $\begin{array}{l}\text { - Will require process to inform/motivate patients } \\
\text { - Will need to have advocacy groups take on this agenda } \\
\text { - Notable expenses for such campaign }\end{array}$ & 5.4 \\
\hline 6.9 & $\begin{array}{l}\text { Education and } \\
\text { knowledge }\end{array}$ & $\begin{array}{l}\text { Teach shared decision-making skills } \\
\text { (with good and poor examples) in } \\
\text { continuing medical, residency and } \\
\text { medical school education }\end{array}$ & $\begin{array}{l}\text { - Teaching skills is for more difficult than teaching } \\
\text { knowledge and will require models, practice and } \\
\text { feedback }\end{array}$ & 4.8 \\
\hline 6.9 & $\begin{array}{l}\text { Financial and } \\
\text { regulation }\end{array}$ & $\begin{array}{l}\text { Implement SDM and cancer } \\
\text { screening communication as } \\
\text { quality standard (e.g., pay for } \\
\text { performance) and adjust } \\
\text { reimbursement }\end{array}$ & $\begin{array}{l}\text { - May obtain minimal performance, with just } \\
\text { checkboxes EMR measures } \\
\text { - Regulation is "easy" for EMR capable } \\
\text { systems - developing the standard of care is } \\
\text { difficult }\end{array}$ & 3.3 \\
\hline 6.7 & $\begin{array}{l}\text { Financial and } \\
\text { regulation }\end{array}$ & $\begin{array}{l}\text { Do not allow PSA test ordering } \\
\text { until there is documentation of } \\
\text { SDM in the EMR }\end{array}$ & $\begin{array}{l}\text { - Will require that each EMR be set up to disallow } \\
\text { ordering until documentation is provided }\end{array}$ & 5.8 \\
\hline 6.4 & $\begin{array}{l}\text { Communication } \\
\text { and messaging }\end{array}$ & $\begin{array}{l}\text { Provide clinicians with } \\
\text { interactive tools to allow men } \\
\text { to visualize risks and benefits } \\
\text { and aid in their understanding } \\
\text { (e.g., smart phone apps) }\end{array}$ & $\begin{array}{l}\text {-Will need development, funding and regular updating. } \\
\text { - Will need to be done by CDC or other credible source }\end{array}$ & 6.2 \\
\hline 6.3 & $\begin{array}{l}\text { Financial and } \\
\text { regulation }\end{array}$ & $\begin{array}{l}\text { Benchmark PSA testing by } \\
\text { providing data on other } \\
\text { provider's PSA testing rates }\end{array}$ & - Could be done within \& between group practices & 4.6 \\
\hline 6.2 & $\begin{array}{l}\text { Communication } \\
\text { and messaging }\end{array}$ & $\begin{array}{l}\text { Provide clear and simple } \\
\text { messages that providers can use } \\
\text { with their patients }\end{array}$ & $\begin{array}{l}\text { - Such messages need to be in a central repository } \\
\text { or database and be easily accessible. }\end{array}$ & 5.8 \\
\hline 5.9 & $\begin{array}{l}\text { Communication } \\
\text { and messaging }\end{array}$ & $\begin{array}{l}\text { Provide table of effective } \\
\text { preventive strategies based on } \\
\text { the expected benefit to the } \\
\text { patient so that patients and } \\
\text { providers can allocate their time } \\
\text { appropriately }\end{array}$ & $\begin{array}{l}\text { - Needs to be produced by credible source } \\
\text { - Needs to be disseminated } \\
\text { - Needs to be simple and understandable to both } \\
\text { patients and providers }\end{array}$ & 5.9 \\
\hline 5.9 & $\begin{array}{l}\text { Communication } \\
\text { and messaging }\end{array}$ & $\begin{array}{l}\text { Convey in messaging that groups } \\
\text { are "making money" from testing } \\
\text { decisions }\end{array}$ & $\begin{array}{l}\text { - Will be politically difficult } \\
\text { - Will create inter-professional discord } \\
\text { - Will need to be done by outside advocacy groups }\end{array}$ & 5.6 \\
\hline 5.5 & $\begin{array}{l}\text { Education and } \\
\text { knowledge }\end{array}$ & $\begin{array}{l}\text { Provide direct observational } \\
\text { feedback to clinician on their } \\
\text { counseling and shared decision- } \\
\text { making skills }\end{array}$ & $\begin{array}{l}\text { - Easier to do in medical school and residency } \\
\text { - No real mechanism to do this in practice } \\
\text { - Could more easily be done by health care systems } \\
\text { (such as VA or Kaiser) where such resources and } \\
\text { motivation exists }\end{array}$ & 6.2 \\
\hline 5.4 & $\begin{array}{l}\text { Education and } \\
\text { knowledge }\end{array}$ & $\begin{array}{l}\text { Provide guidelines on when to } \\
\text { use SDM and when to use more } \\
\text { directed decision-making }\end{array}$ & $\begin{array}{l}\text { - Such education is difficult to disseminate } \\
\text { and is best done in training programs not in CME } \\
\text { environments }\end{array}$ & 5.8 \\
\hline 5.0 & $\begin{array}{l}\text { Financial and } \\
\text { regulation }\end{array}$ & $\begin{array}{l}\text { Use accreditation lever } \\
\text { (mandatory testing or module } \\
\text { completion for recertification) }\end{array}$ & $\begin{array}{l}\text { - Will require broad buy-in from multiple } \\
\text { constituencies }\end{array}$ & 4.1 \\
\hline 4.4 & $\begin{array}{l}\text { Financial and } \\
\text { regulation }\end{array}$ & $\begin{array}{l}\text { Work with professional } \\
\text { organizations to promote } \\
\text { awareness and skill building }\end{array}$ & $\begin{array}{l}\text { - This would need to involve many professional } \\
\text { and advocacy groups }\end{array}$ & 4.2 \\
\hline 4.3 & $\begin{array}{l}\text { Financial and } \\
\text { regulation }\end{array}$ & $\begin{array}{l}\text { Prevent ordering of PSA test unless } \\
\text { it is linked to patient SDM signed } \\
\text { note (using HIV as a model) }\end{array}$ & $\begin{array}{l}\text { - Requires both system approval and programming } \\
\text { of the EMR }\end{array}$ & 3.5 \\
\hline 4.0 & $\begin{array}{l}\text { Communication } \\
\text { and messaging }\end{array}$ & $\begin{array}{l}\text { Re-label "prostate cancer" to } \\
\text { another name that better captures } \\
\text { the varied nature of abnormal cells }\end{array}$ & $\begin{array}{l}\text { - At best will be a slow evolution and there are } \\
\text { powerful forces who will continue to push for it to } \\
\text { be considered "cancer" }\end{array}$ & 3.3 \\
\hline 3.9 & Behavior & $\begin{array}{l}\text { Provide data to providers on } \\
\text { patients (or percentage of patients) } \\
\text { who don't opt in to PSA testing so } \\
\text { they know that not everyone is } \\
\text { selecting "testing" }\end{array}$ & $\begin{array}{l}\text { - Will require each health care system or laboratory } \\
\text { to compile this data separate } \\
\text { - If you do this nationally it may not have } \\
\text { as much meaning to any given provider or patient }\end{array}$ & 5.9 \\
\hline 3.6 & Behavior & $\begin{array}{l}\text { Measure quality of care in the } \\
\text { doctor-patient encounter and } \\
\text { provide bonus when SDM is done } \\
\text { well (may be more related to } \\
\text { physician than patient) }\end{array}$ & $\begin{array}{l}\text { Would have cost implications to physicians and } \\
\text { health care systems }\end{array}$ & 2.0 \\
\hline
\end{tabular}


Table 2. Patient Issues Around Prostate Cancer Screening Discussions

\begin{tabular}{|c|c|c|c|c|}
\hline $\begin{array}{l}\text { Average rank } \\
\text { for effectiveness } \\
\text { in achieving } \\
\text { behavioral } \\
\text { change (1-7, } \\
7=\text { maximum) }\end{array}$ & Theme & Item & $\begin{array}{l}\text { Barriers to change related to each } \\
\text { item }\end{array}$ & $\begin{array}{l}\text { Average rank } \\
\text { for effort to } \\
\text { achieve change } \\
\text { (1-7, } \\
7=\text { maximum) }\end{array}$ \\
\hline 5.5 & $\begin{array}{l}\text { Education and } \\
\text { knowledge }\end{array}$ & $\begin{array}{l}\text { Provide tools to patients that allow them to } \\
\text { prepare and learn about cancer screening, } \\
\text { before they meet with the doctor to } \\
\text { improve use of visit time }\end{array}$ & $\begin{array}{l}\text { - Dissemination will be a problem, best } \\
\text { managed by health care systems or } \\
\text { advocacy groups } \\
\text { - Will require high level of patient } \\
\text { related literacy } \\
\text { - Will need to address different education } \\
\text { levels and different languages and cultural } \\
\text { groups } \\
\text { - Will need to be kept up to date } \\
\text { - Will require a national curriculum }\end{array}$ & 6.8 \\
\hline 5.5 & Behavior & $\begin{array}{l}\text { Unbundle cancer screening discussions } \\
\text { from PCP visit and place in "wellness } \\
\text { clinic" or "group prevention clinic" }\end{array}$ & $\begin{array}{l}\text { - Would need to rearrange clinic and } \\
\text { staff, and patient flow/scheduling }\end{array}$ & 3.6 \\
\hline 5.2 & Behavior & $\begin{array}{l}\text { Provide pre-visit phone call (or other } \\
\text { communication) perhaps from staff to prime } \\
\text { patient on content and questions to ask }\end{array}$ & $\begin{array}{l}\text { - Would need to have system to deliver } \\
\text { these calls }\end{array}$ & 3.8 \\
\hline 4.9 & $\begin{array}{l}\text { Attitudes and } \\
\text { beliefs }\end{array}$ & $\begin{array}{l}\text { Pay attention to framing effect. Reframe } \\
\text { discussions as health promotions vs. } \\
\text { detection of cancer/disease }\end{array}$ & $\begin{array}{l}\text { - Would need to develop tools and have } \\
\text { system and clinician buy-in }\end{array}$ & 4.3 \\
\hline 4.8 & $\begin{array}{l}\text { Education and } \\
\text { knowledge }\end{array}$ & $\begin{array}{l}\text { Use of high quality decision aides in } \\
\text { doctor-patient interactions }\end{array}$ & $\begin{array}{l}\text { - Would need to develop tools and have } \\
\text { system and clinician buy-in }\end{array}$ & 4.5 \\
\hline 4.8 & $\begin{array}{l}\text { Communication } \\
\text { and messaging }\end{array}$ & $\begin{array}{l}\text { Provide messaging around the benefits of } \\
\text { not testing and the concept that "less may } \\
\text { be more" }\end{array}$ & $\begin{array}{l}\text { - Would need to develop tools and have } \\
\text { system and clinician buy-in }\end{array}$ & 4.5 \\
\hline 4.6 & $\begin{array}{l}\text { Communication } \\
\text { and messaging }\end{array}$ & $\begin{array}{l}\text { Encourage patients to be as involved in } \\
\text { decision-making to the as they wish to be } \\
\text { - Knows there is a decision to be made } \\
\text { - Knows there are various levels of } \\
\text { involvement they can choose } \\
\text { - Knows a bit about the decision } \\
\text { - Knows what questions to ask }\end{array}$ & $\begin{array}{l}\text { - Would need to develop method of } \\
\text { delivery/dissemination of value scales } \\
\text { and educational materials } \\
\text { - Physicians might be put off by patients } \\
\text { who wanted more time and explanation } \\
\text { than they could provide }\end{array}$ & 4.6 \\
\hline 4.4 & $\begin{array}{l}\text { Financial and } \\
\text { regulation }\end{array}$ & $\begin{array}{l}\text { Waive co-payment or provide other } \\
\text { incentives for patients that engage in SDM }\end{array}$ & $\begin{array}{l}\text { - Would have cost implications to } \\
\text { physicians and health care systems } \\
\text { - May have small, but important effect }\end{array}$ & 3.4 \\
\hline 4.1 & $\begin{array}{l}\text { Attitudes and } \\
\text { beliefs }\end{array}$ & $\begin{array}{l}\text { Have patients be explicit about how much } \\
\text { they value different outcomes (being free of } \\
\text { cancer, being free of side effects, etc.) }\end{array}$ & $\begin{array}{l}\text { - Would need to develop tools and find } \\
\text { appropriate time and setting to assess } \\
\text { values } \\
\text { - Preferences are often not predictive of } \\
\text { actions made when confronted with } \\
\text { actual decisions } \\
\text { - Would need to explain screening and } \\
\text { side effects in understandable manner } \\
\text { taking into account educational level, } \\
\text { culture and language }\end{array}$ & 4.0 \\
\hline 3.3 & $\begin{array}{l}\text { Education and } \\
\text { knowledge }\end{array}$ & $\begin{array}{l}\text { Provide patients with life expectance } \\
\text { calculators, dashboards and guidelines to } \\
\text { review with their doctors }\end{array}$ & - Requires additional development & 3.4 \\
\hline 3.3 & $\begin{array}{l}\text { Education and } \\
\text { knowledge }\end{array}$ & $\begin{array}{l}\text { Provide value assessment tools for } \\
\text { patients to complete }\end{array}$ & $\begin{array}{l}\text { - Should be incorporated seamlessly } \\
\text { into EHRs and decision-aids }\end{array}$ & 3.0 \\
\hline
\end{tabular}

Health Care Systems. Not surprisingly, many of the communication approaches recommended for health care systems were complex and costly (Table 3). Participants felt an essential step would be to change reimbursement strategies so that time spent on careful PrCS discussions would be adequately reimbursed. The cost-effectiveness of this strategy would need to be examined, with a likely reduction in low-yield testing, biopsies and surgery. The group also encouraged creative thinking around developing incentives intended to improve physical PrCS communication. Almost all participants endorsed the idea to incentivize documentation of SDM as a regularly monitored quality control measure but recognized the difficulties that would surround implementation.

Participants expressed the concern that health care systems should take responsibility for helping men to understand they have choices in health care as well as giving them the knowledge and tools to make informed decisions. They suggested that celebrities might be more effective at communicating messages than traditional approaches such as mailings or posters in doctor's offices. They strongly encouraged development of interactive, engaging and customizable eLearning tools that could be used in the office or provided to individuals (apps or web-based decision support interventions) 
Table 3. Improving Health System Behaviors and Public Education Around Prostate Cancer Screening Discussions

\begin{tabular}{|c|c|c|c|c|}
\hline $\begin{array}{l}\text { Average rank for } \\
\text { effectiveness in } \\
\text { achieving behavioral } \\
\text { change (1-7, } \\
7=\text { maximum) }\end{array}$ & Theme & Item & $\begin{array}{l}\text { Barriers to change related to } \\
\text { each item }\end{array}$ & $\begin{array}{l}\text { Average rank } \\
\text { for effort to } \\
\text { achieve } \\
\text { change (1-7, } \\
7=\text { maximum) }\end{array}$ \\
\hline 5.7 & $\begin{array}{l}\text { Attitudes and } \\
\text { beliefs }\end{array}$ & $\begin{array}{l}\text { Use EMR to educate men around notion that } \\
\text { they have a choice in health care and they } \\
\text { need to be active participants in decision- } \\
\text { making }\end{array}$ & $\begin{array}{l}\text { - Dissemination and outreach will } \\
\text { be crucial } \\
\text { - Will take time to change } \\
\text { expectations and roles } \\
\text { - Will take time and resources to } \\
\text { develop tools }\end{array}$ & 5.8 \\
\hline 5.3 & $\begin{array}{l}\text { Communication } \\
\text { and messaging }\end{array}$ & $\begin{array}{l}\text { Use celebrities to counter detail the pro- } \\
\text { testing message and provide credible } \\
\text { messages around asking questions }\end{array}$ & $\begin{array}{l}\text { - Celebrities may question motives } \\
\text { - Costly }\end{array}$ & 4.6 \\
\hline 5.0 & $\begin{array}{l}\text { Education and } \\
\text { knowledge }\end{array}$ & $\begin{array}{l}\text { Provide education around myths and } \\
\text { misconceptions about cancer screening }\end{array}$ & $\begin{array}{l}\text { - Will need tool to disseminate and } \\
\text { many men may not have access or } \\
\text { sophistication with web-based } \\
\text { tools }\end{array}$ & 3.3 \\
\hline 4.9 & $\begin{array}{l}\text { Communication } \\
\text { and messaging }\end{array}$ & $\begin{array}{l}\text { Partner with other health care organizations } \\
\text { and support groups }\end{array}$ & $\begin{array}{l}\text { - Will require development of } \\
\text { partnerships and trust } \\
\text { - Would be best if all primary care } \\
\text { groups would stand together on } \\
\text { this issue }\end{array}$ & 4.3 \\
\hline 4.9 & Behaviors & $\begin{array}{l}\text { Provide non-physicians health educators to } \\
\text { engage in communication and counseling }\end{array}$ & $\begin{array}{l}\text { - Would need to hire/retrain staff to } \\
\text { accomplish task }\end{array}$ & 3.8 \\
\hline 4.8 & $\begin{array}{l}\text { Education and } \\
\text { knowledge }\end{array}$ & $\begin{array}{l}\text { Provide education so that the public } \\
\text { understand that/procedures have harms and } \\
\text { benefits }\end{array}$ & $\begin{array}{l}\text { - Will need tool to disseminate. } \\
\text { Many men may not have access or } \\
\text { experience with web-based tools }\end{array}$ & 3.4 \\
\hline 4.7 & Behaviors & $\begin{array}{l}\text { Work with EMR programmers to provide } \\
\text { reminders and tools to assist in SDM in } \\
\text { office or prior to visit }\end{array}$ & $\begin{array}{l}\text { - Will require health care systems } \\
\text { to engage in providing tools to } \\
\text { patients }\end{array}$ & 4.5 \\
\hline 4.4 & $\begin{array}{l}\text { Financial and } \\
\text { regulation }\end{array}$ & $\begin{array}{l}\text { Learn from mammogram and anticipate } \\
\text { strong opposition from those with much to } \\
\text { lose }\end{array}$ & $\begin{array}{l}\text { The two scenarios may not be } \\
\text { identical }\end{array}$ & 3.9 \\
\hline 4.3 & $\begin{array}{l}\text { Financial and } \\
\text { regulation }\end{array}$ & Increase visit time & $\begin{array}{l}\text { - Would have cost implications to } \\
\text { physicians and health care systems }\end{array}$ & 2.2 \\
\hline 4.0 & $\begin{array}{l}\text { Education and } \\
\text { knowledge }\end{array}$ & $\begin{array}{l}\text { Create national curriculum on health care } \\
\text { screening }\end{array}$ & $\begin{array}{l}\text { - Would be large effort with large } \\
\text { costs and multiple constituencies }\end{array}$ & 2.9 \\
\hline 3.8 & Behaviors & $\begin{array}{l}\text { Use interactive tools (apps or web tools) that } \\
\text { link to the electronic medical record to } \\
\text { collect answers from patients to questions } \\
\text { about their values, preferences or areas of } \\
\text { uncertainty. Once in the EMR this } \\
\text { information will then be used by clinicians } \\
\text { to guide their discussions }\end{array}$ & $\begin{array}{l}\text { - Will be hard to get experts to } \\
\text { agree } \\
\text { - Physicians will not like it if it } \\
\text { extends time } \\
\text { - Patients often can not remember } \\
\text { to bring medication list to } \\
\text { doctor-will need reminders } \\
\text { - Will need to tailor message to } \\
\text { different groups }\end{array}$ & 4.8 \\
\hline 3.7 & $\begin{array}{l}\text { Attitudes and } \\
\text { beliefs }\end{array}$ & $\begin{array}{l}\text { Separate the economics of cost saving from } \\
\text { evidence for and against testing }\end{array}$ & $\begin{array}{l}\text { - This may require more advanced } \\
\text { discussion than most men would } \\
\text { care to know }\end{array}$ & 3.4 \\
\hline 3.6 & $\begin{array}{l}\text { Communication } \\
\text { and messaging }\end{array}$ & $\begin{array}{l}\text { Convey that the pro-testing community is } \\
\text { being supported by those who make profit } \\
\text { off the test (3) }\end{array}$ & $\begin{array}{l}\text { - Caution in not wanting to create } \\
\text { negative messaging }\end{array}$ & 3.6 \\
\hline 3.5 & $\begin{array}{l}\text { Communication } \\
\text { and messaging }\end{array}$ & $\begin{array}{l}\text { Provide information on screening tests } \\
\text { that are effective and those that are not } \\
\text { (NNT and NNH), as well as cost- } \\
\text { effectiveness } 13 \text { and } 15\end{array}$ & $\begin{array}{l}\text { - Will need tool to disseminate } \\
\text { and many men may not have } \\
\text { access or sophistication with } \\
\text { web-based tools }\end{array}$ & 4.4 \\
\hline 2.9 & $\begin{array}{l}\text { Attitudes and } \\
\text { beliefs }\end{array}$ & $\begin{array}{l}\text { Use word other than screening in that } \\
\text { screening is perceived as a general good } 8\end{array}$ & $\begin{array}{l}\text { Will be hard to do this on a } \\
\text { national level and it will take } \\
\text { years }\end{array}$ & 3.2 \\
\hline
\end{tabular}

and that would interface with the electronic health records. For instance, clinicians could then review patient responses on values/preferences for SDM around prostate cancer screening. Doctors could then direct discussion to specific areas of confusion or uncertainty. Most importantly, participants felt these decision support interventions would be most useful to clinicians by allowing them to focus available time on areas that deserved the most attention and also allow quality monitoring of physician-patient communication and decision-making.

\section{DISCUSSION}

Screening for cancer raises complex issues involving risks and benefits to the patient. The ultimate screening decision 
belongs to the patient informed by best evidence, expert judgment and personal values, and acquisition of clear information is of paramount importance. Information aside, cancer screening discussions are often emotional and influenced by personal, professional and societal factors. This expert panel on communication about prostate cancer screening sought to determine methods to both provide high-quality information and help individuals make valueconcordant health choices.

Importantly, our panelists included a variety of stakeholders. Their viewpoints differed, as each group was familiar with a different piece of the prostate cancer screening puzzle. For instance, patient advocates often wanted to protect patients from the harms of testing that were not honestly or openly discussed and from perceived biased viewpoints of specialists. The primary care physicians treated many of the complications of surgery or radiation and did not directly see the benefit of populationlevel prostate cancer screening. Specialists saw patients who had or were worried about advanced cancer; they strongly believed their procedures saved lives and improved the quality of men's lives. When our group came to an impasse over a specific perspective, we acknowledged disagreement and moved on to discussion in other areas.

By addressing intervention effectiveness, these recommendations are intended to help providers and others determine the wisdom of particular strategies in pursuit of value-concordant PrCS decision-making. Clearly, potential effectiveness is dependent upon using the right social lever for the right condition-design, engagement strategy and implementation must all be thoroughly considered. ${ }^{23}$

Multi-faceted interventions utilizing social media, health messages and financial incentives may improve PrCS decision-making. For example, coupling public health announcements on tobacco cessation in California with an increase in cigarette sales tax led to significant decreases in cigarette consumption. ${ }^{36-38}$ Policies that regulate salt ingestion are predicted to reduce blood pressure, risks of cardiovascular disease and provide substantial savings. ${ }^{39}$ Similarly, doubling the price of alcohol is projected to reduce alcohol-related and sexually transmitted diseases by $6 \%{ }^{40,41}$ These social policy changes do not address informed decision-making in clinical care but instead use other societal levers to improve day-to-day decisions leading to the adoption of healthy behaviors. The financial impact of these interventions on the lives of patients was enough to make individual reconsider the value of a cigarette or a drink at the time of purchase. As such, panel participants recommended consideration of new financial/regulatory incentives to improve physician-patient communication around prostate cancer screening to supplement emerging decision-support technology. For instance, financial incentives may encourage patients to discuss cancer screening and preventive behaviors with their physicians-and provide the opportunity for physicians to more thoughtfully engage patients around the risks and benefits of specific interventions.

The panelists strongly encouraged more innovative use of new social and interactive media tools to improve both physician and patient decision-making, rather than simply improving knowledge acquisition. ${ }^{42}$ Decision support interventions (including for prostate cancer screening) present information in an understandable manner, have been shown to increase knowledge, reduce decisional conflict, clarify values and lead patients to take a more active role in their health care. ${ }^{31,32}$ Decision support interventions have been shown on meta-analysis to reduce PrCS with PSA. ${ }^{43}$ However, these patient-focused decision support interventions are infrequently used in clinical practice, often due to lack of awareness of the tools, the additional time taken to utilize the tool or the lack of access to the tool at the point of care. ${ }^{31,32}$ Well-constructed decision support interventions (icon arrays, stadium diagrams, roulette wheels) address the complexity of medical and numerical information, biases and incorporate patient preferences. Our group emphasized that having a trusted central site (such as within AHRQ, AAMC MedPortal or CDC) with vetted programs would help overcome some of the access issues. System redesign might be necessary to help with decision-aid implementation, with additional time/space allocated to have patients (and physicians) review the decision support interventions. Such aids can provide useful customized output to prepare patients for a discussion with their health care provider. ${ }^{23,44-51}$

Participants felt that improved physician communication skills should be addressed through educational interventions at three levels-medical school (undergraduate medical education), residency training (graduate medical education) and continuing medical education. Residency programs are increasingly emphasizing patient-oriented outcomes, with attention being paid to enhanced communication skills. ${ }^{52}$ Evidence suggests that traditional CME does not effectively improve physician practice-based behaviors or decisions, ${ }^{53-55}$ and $\mathrm{CME}$ has tended to ignore assisting clinicians to improve communication skills. Assessment, feedback interventions and recertification examinations offer opportunities to increase clinically meaningful outcomes if they can focus more on clinical behaviors than on factual recall. Panel members also felt that offering providers financial incentives is a tool to facilitate improved decision-making.

Health systems also have an important role to play in improving communications around PrCS, including system and clinic flow changes to systematize screening educational resources, discussions and incentives. Some health care systems have found great success in using reminders to stimulate communication around specific topics (via electronic medical records, emails and social networks). These systems can be expensive, but early reports indicate 
they seem to reduce overall costs and improve quality (Kaiser Permanente, personal communication).

In summary, effective communication around prostate cancer screening is essential to match available evidence with patient values and desires. This article provides a background for how such communication might be approached from the perspective of providers, patients and the health care system. While all of the suggested interventions require resources to develop and evaluate, the lessons learned now will enhance screening communication in the future.

ACKNOWLEDGMENTS: We would like to thank our panelists for their input and collaborative spirit. Group participants (alphabetically by group):

Health Care Provider Communication and Education Issues: Daniel Barocas, MD (Vanderbilt University); Russell P Harris, MD, MPH (USPSTF, University of North Carolina); Joanne Schottinger, MD (Kaiser Permanente, California); Malathi Srinivasan, MD (University of California, Davis); Tim Wilt, MD, MPH (University of Minnesota School of Medicine)

Patient Communication and Shared Decision-Making Issues: Robert German DrPh, MPH; Elizabeth I Heath, MD (Wayne State University); Linda Kinsinger, MD, MPH (US Department of Veterans'Affairs, National Center for Health Promotion and Disease Prevention); Richard L. Kravitz, MD, MSPH (University of California, Davis); Elissa Schuler-Adair, PhD (Consumers Union)

Health Care Systems and the Public Issues: Shannon Brownlee, MS (Dartmouth University and New America Foundation); Joseph Capella, MD (University of Pennsylvania); Barbara Powe, $P h D, R N$ (American Cancer Society); Punam Keller, MBA, PhD (Dartmouth Univeristy School of Business)

Centers for Disease Control and Prevention: Galen Cole, $\mathrm{PhD}$ MPH; Djenaba Joseph, MD, MPH; Marcus Plescia, MD, MPH; Lisa C. Richardson, $M D, M P H$.

Oak Ridge Institute for Science and Education: Richard Tardif, $\mathrm{PhD}$, Sheri Hester, MSLS, Ben Wilburn, BA, Eileen Haag, BSOE, M.Ed., and Pamela Hadley, AAS.

Funding: Funding for and coordination of the workgroup was provided by the Oak Ridge Institute for Science and Education (ORISE) under contract with the Centers for Disease Control and Prevention.

Disclaimers: The findings and conclusions in this report are those of the authors and do not necessarily represent the official position of the Centers for Disease Control and Prevention.

Open Access: This article is distributed under the terms of the Creative Commons Attribution License which permits any use, distribution, and reproduction in any medium, provided the original author(s) and the source are credited.

Corresponding Author: Michael Wilkes, $M D, P h D$; , University of California, Davis School of Medicine, 1 Shield Avenue, Sacramento, CA, USA (e-mail: mswilkes@ucdavis.edu).

\section{REFERENCES}

1. Lin K, Lipsitz R, Miller T, Janakiraman S. Benefits and harms of prostatespecific antigen screening for prostate cancer: an evidence update for the US Preventive Services Task Force. Ann Intern Med. 2008;149:192-9.

2. Chou R, Croswell JM, Dana T, Bougatsos C, et al. Screening for prostate cancer: a review of the evidence for the US Preventive services task force. Ann Intern Med. 2011;155(11):762-71.

3. US Preventive Services Task Force. Screening for prostate cancer: US Preventive Services Task Force recommendation statement. Ann Intern Med. 2008;149:185-91.
4. US Cancer Statistics Working Group. United States Cancer Statistics: 1999-2007 Incidence and Mortality Web-based Report. Atlanta: US Department of Health and Human Services, Centers for Disease Control and Prevention and National Cancer Institute; 2010. Available at: www.cdc.gov/uscs.

5. Legare F, Ratte S, Stacey D, Kryworuchko J, Gravel K, Graham ID, Turcotte S. Interventions for Improving the Adoption of Shared Decision Making by Healthcare Professionals (Review). John Wiley \& Sons, Ltd.; 2010.

6. McKinstry B. Do patients wish to be involved in decision making in the consultation? A cross-sectional survey with video vignettes. BMJ. 2000;321:867-71.

7. Say RE, Thomson R. The importance of patient preferences in treatment decisions-challenges for doctors. BMJ. 2003;327:542-5.

8. Braddock CH, Edwards KA, Hasenberg NM, Laidley TL, Levinson W. Informed decision making in outpatient practice: time to get back to basics. JAMA. 1999;282:2313-20.

9. Godolphin W. Understanding decision-making in healthcare and law. Healthc Qual. 2007;12:186-90.

10. Pignone M. Weighing the benefits and downsides of prostate-specific antigen screening. Arch Intern Med. 2009;169(17):1554-5.

11. Barratt AL, Stockler MR. Screening for prostate cancer: explaining how new trial results and their implications to patients. MJA. 2009; 191(4):226-9.

12. Smith RA, Cokkinides V, Levin B, et al. American Cancer Society guidelines for the early of detection of cancer. The American Cancer Society. CA Cancer J Clin. 2002;52:8-22.

13. American Medical Association. Cancer screening guidelines [perform a search for specific types of cancer]. Retrieved September 20, 2000, from the World Wide Web: http://www.ama-assn.org.

14. National Health Service. 2011. http://www.cancerscreening.nhs.uk/ prostate/prostate-patient-info-sheet.pdf

15. American Cancer Society. Revised Prostate Cancer Screening Guidelines: What Has-and Hasn't-Changed. 2010. Retrieved Jan 2012. http:// www.cancer.org/Cancer/news/News/revised-prostate-cancer-screening-guidelines

16. USPSTF. May 2012. http://www.uspreventiveservicestaskforce.org/ prostatecancerscreening.htm

17. Ransohoff DF, Collins MM, Fowler FJ. Why is prostate cancer screening so common when the evidence is so uncertain? A system without negative feedback. Am J Med. 2002;113:663-7.

18. Aronowitz RA. Do not delay: breast cancer and time, 1900-1970. Milbank Q. 2001;9(3):355-86.

19. Schwartz LM, Woloshin S, Fowler FJ, Welch HG. Enthusiasm for cancer screening in the United States. JAMA. 2004;291(1):71-8.

20. Barry MJ, Wescott PH, Reifler EJ, Chang Y, Moulton BW. Reactions of potential jurors to a hypothetical malpractice suit alleging failure to perform a prostate-specific antigen test. J Law Med Ethics. 2008;36(2):396-402, 214

21. Merenstein D. A piece of my mind. Winners and losers. JAMA. 2004;291(1):15-6

22. Kahneman D, Tversky A. Choices, values, and frames. Am Psychol. 1984;39:341-50.

23. Keller PA, Lehmann DR. Designing effective health communications: a meta-analysis. J Public Policy Mark. 2008;27(2):117-30.

24. Andreasen AR. Social Marketing in the 21 st Century. Thousand Oaks: Sage Publications; 2006.

25. Dobrow MJ, Goel V, Lemieux-Charles L, Black NA. The impact of context on evidence utilization: a framework for expert groups developing health policy recommendations. Soc Sci Med. 2006;63:1811-24.

26. Kerfoot BP, Holmberg EF, Lawler EV, Krupat E, Conlin PR. Practitionerlevel determininants of inappropriate prostate-specific antigen screening. Arch Intern Med. 2007;167(13):1367-72.

27. Elwyn G, Frosch D, Volandes AE, Edwards A, Montori VM. Investing in deliberation: a definition and classification of decision support interventions for people facing difficult health decisions. Med Decis Making. 2010;30(6):701-11

28. Farrell MH, Murphy MA, Schneider CE. How underlying patient beliefs can affect physician-patient communication about prostate-specific antigen testing. Eff Clin Pract. 2002;5(3):120-9.

29. Wolf SH. Screening for prostate cancer. In: United States Preventative Services Task Force, ed. The Guide to Clinical Preventative Services. 2nd ed. Baltimore: Williams \& Wilkins; 1996:119-34.

30. Brody H. Transparency: informed consent in primary care. Hast Cent Rep. 1989;19:5-9. 
31. Stacey D, Bennett CL, Barry MJ, et al. Decision aids for people facing health treatment or screening decisions. Cochrane Database Syst Rev. $2011 ;(10): C D 001431$.

32. Hoffman JR, Wilkes MS, Day FC, Bell DS, Higa JK. The roulette wheel: an aid to informed decision making. PLoS Med. 2006;3(6):e137. doi:10.1371/journal.pmed.

33. Epstein RM, Street RL, Jr. Patient-Centered Communication in Cancer Care: Promoting Healing and Reducing Suffering. National Cancer Institute, NIH Publication No. 07-6225. Bethesda, MD, 2007.

34. Elwyn G, O'Connor A, Stacey D, et al. Developing a quality criteria framework for patient decision aids: online international Delphi consensus process. BMJ. 2006;333:417.

35. Scott JC, Robertson BJ. Kaiser Colorado's Cooperative Health Care Clinic: a group health approach to patient care. Manag Care Q. 4(3):41-5.

36. Chaloupka F. Macro-social influences: the effects of prices and tobacco control policies on the demand for tobacco products. Nicotine Tob Res. 1999; 1(Suppl 1):S105-9.

37. Chaloupka F, Pacula R. An Examination of Gender and Race Differences in Youth Smoking Responsiveness to Price and Tobacco Control Policies, National Bureau of Economic Research, Working Paper 6541, April 1998.

38. Hu T-W, Sung HY, Keeler TE. Reducing cigarette consumption in California: tobacco taxes vs an anti-smoking media campaign. Am J Public Health. 1995;85:1218-22.

39. Bibbins-Domingo K, Chertow GM, Coxson PG, Moran A, Lightwood JM, Pletcher MJ, et al. Projected effect of dietary salt reductions on future cardiovascular disease. N Engl J Med. 2010;362:590-9.

40. Cohen DA, Wu S, Farley TA. Comparing the cost-effectiveness of HIV prevention interventions. J Acquir Immune Defic Syndr. 2004;37:1404-14.

41. Wagenaar A, Tobler AL, Komro KA. Effects of alcohol tax and price policies on morbidity and mortality: a systematic review. Am J Public Health. 2010;100:2270-8.

42. Guide to Community Preventive Services. Cancer prevention \& control, provider-oriented screening interventions: assessment \& feedback (abbreviated). www.thecommunityguide.org/cancer/screening/ provider-oriented/assessment a.html. Accessed 12/12/2011.
43. Volk RJ, Hawley SK, Holden EW, et al. Trials of decision aids for prostate cancer screening: a systematic review. Am J Prev Med. 2007;33:428-34.

44. Elwyn G, Edwards A, Gwyn R, Grol R. Towards a feasible model for shared decision making: focus group study with general practice registrars. BMJ. 1999;319:753-6.

45. Edwards A, Elwyn G, Mulley A. Explaining risks: turning numerical data into meaningful pictures. BMJ. 2002;324:827-30.

46. Gigerenzer G, Edwards A. Simple tools for understanding risks: from innumeracy to insight. BMJ. 2003;327:741-4.

47. Paling J. Strategies to help patients understand risks. BMJ. 2003;327:745-8.

48. Barratt A, Trevena L, Davey HM, McCaffery $\mathbf{K}$. Use of decision aids to support informed choices about screening. BMJ. 2004;329:507-10.

49. O'Connor AM, Bennett CL, Stacey D, et al. Decision aids for people facing health treatment or screening decisions. Cochrane Database Syst Rev. 2009;3:CD001431.

50. Legare F, Ratte S, Gravel K, Graham ID. Barriers and facilitators to implementing shared decision-making in clinical practice: update of a systematic review of health professionals' perceptions. Patient Educ Couns. 2008;73(3):526-35.

51. Kawamoto K, Houlihan C, Balas EA, Lobach DF. Improving clinical practice using clinical decision support systems: a systematic review of trials to identify features critical to success. BMJ. 2005;330:765.

52. ACGME General Competencies: Competency Definitions and Recommended Practice Performance Tools. Accreditation Council for Graduate Medical Education. Chicago, IL. posted: October 18, 2007. http:// www.acgme.org/acWebsite/RRC 430/430 CompetencyDefinitions RO_ED_10182007.pdf (Accessed: January 28, 2012)

53. Cantillon P. Does continuing medical education in general practice make a difference? BMJ. 1999;318:1276.

54. Davis DA, Thomson MA, Oxman AD, et al. Changing physician performance. A systematic review of the effect of continuing medical education strategies. JAMA. 1995;274(9):700-5.

55. Bloom BS. Effects of continuing medical education on improving physician clinical care and patient health: a review of systematic reviews. Int J Technol Assess Health Care. 2005;21(3):380-5. 